\title{
Konstruksi Plasmid Pengekspresi Antigen Rekombinan Berbasis Epitop Multipel untuk Deteksi Antibodi Anti-HCV
}

\author{
Plasmid Construction of Multiple Epitope-Based Recombinant Antigen Expression for the Detection of \\ Anti-HCV Antibodies
}

\author{
Dian Amirulloh, ${ }^{1}$ Silvia Tri Widyaningtyas, ${ }^{2}$ dan Budiman Bela ${ }^{* 2,3}$ \\ ${ }^{1}$ Program Magister Ilmu Biomedik, Fakultas Kedokteran, Universitas Indonesia, Jl. Salemba Raya No.6 \\ Jakarta Pusat 10430, Indonesia \\ ${ }^{2}$ Pusat Riset Virologi dan Kanker Patobiologi, Fakultas Kedokteran, Universitas Indonesia, Rumah Sakit \\ Cipto Mangunkusumo, Jl. Salemba Raya No.4 Jakarta Pusat 10430, Indonesia \\ ${ }^{3}$ Departemen Mikrobiologi, Fakultas Kedokteran, Universitas Indonesia, Jl. Pegangsaan Timur No.16 \\ Jakarta Pusat 10320, Indonesia \\ *Korespondensi: budiman.bela@yahoo.com
}

Submitted: 02-07-2018; Revised: 13-09-2018; Accepted: 17-09-2018

DOI: https://doi.org/10.22435/mpk.v28i3.39

\begin{abstract}
Abstrak
Infeksi hepatitis $C$ virus (HCV) dapat menyebabkan penyakit hati kronis yang berkembang menjadi sirosis dan kanker hati. Diperkirakan terdapat lebih dari 170 juta penduduk dunia menderita HCV. Diagnosis yang akurat diperlukan untuk memberikan penanganan tepat secara dini, termasuk mencegah penularan virus tersebut lebih lanjut. Tujuan penelitian ini adalah mengonstruksi plasmid pengekspresi antigen rekombinan untuk deteksi antibodi anti-HCV. Gen pengode antigen tersebut dirancang sedemikian rupa sehingga tersusun atas epitop yang bersifat imunodominan, lestari, serta mewakili subtipe HCV yang bersirkulasi di Indonesia maupun global. Selanjutnya gen tersebut dibuat dengan teknik DNA sintetik oleh perusahaan penyedia jasa sintesis DNA dan diterima oleh peneliti dalam bentuk terklona pada plasmid pUC57. Untuk ekspresi pada sel Escherichia coli, gen penyandi antigen rekombinan disubklona dari plasmid pUC57 ke plasmid PQE80L dengan situs pengklonaan BamHI dan Hindlll. Plasmid rekombinan hasil subklona kemudian dipropagasi pada sel Escherichia coli Top10 dan diverifikasi dengan teknik PCR koloni, analisis dengan enzim restriksi dan sekuensing. Gen penyandi antigen rekombinan HCV berbasis epitop multipel (HCV_ME) berukuran $1200 \mathrm{pb}$. Pengklonaan gen tersebut pada vektor pUC57 menghasilkan plasmid pUC57-HCV_ME (3910 pb) dan subklona pada vektor pQE80L menghasilkan plasmid pQE80L-HCV_ME (5909 pb). Berdasarkan pada hasil verifikasi plasmid pQE80L-HCV_ME pengekspresi antigen rekombinan untuk deteksi antibodi anti-HCV telah berhasil dikonstruksi.
\end{abstract}

Kata kunci: HCV; kloning; antigen; epitop; diagnosis

\begin{abstract}
Hepatitis $C$ virus (HCV) infection can cause chronic liver disease that develops into cirrhosis and liver cancer. It is estimated that are more than 170 million of th world's population suffering from HCV. Accurate diagnosis is needed to provide appropriate early treatmen, including preventing further transmission of the virus. The purpose of this study was to construct plasmid expression of recombinant antigen for detection of anti-HCV antibodies. The antigen coding gene is designed so that is composed to epitopes that are immunodominant, sustainable and and represent HCV subtypes circulating in Indonesia and globally. Furthermore, the gene was made by synthetic DNA techniques by DNA synthesis service providers and accepted by the researchers in the form of blinding on the PUC57 plasmid to PQE8OL plasmid with BamHI and HindIII cloning sites. Subcloned recombinant plasmids were then propagated on Top10 Escherichia coli cells and verified by PCR colony tecnique, restriction, and sequencing analysis. HCV recombinant antigen coding gene is $1200 \mathrm{bp}$. Cloning of these gene on the PUC57 vector produced a plasmid pUC57-
\end{abstract}


HCV_ME (3910 bp) and subcloned in the $p Q E 80 L$ vector producing $p Q E 80 L-H C V \_M E$ plasmid (5909bp). Based on verification results of $p Q E 80 L-H C V \_M E$ plasmid the expression of recombinant antigen for detection of anti-HCV antibodies has been successfully constructed.

Keywords: HCV; cloning; antigen; multiepitope; diagnosis

\section{PENDAHULUAN}

Hepatitis C virus (HCV) mulai ditemukan sekitar tahun 1989. Virus tersebut merupakan salah satu penyebab utama penyakit hepatitis. ${ }^{1}$ Penyakit ini diawali dengan terjadinya infeksi akut, kemudian dapat berkembang menjadi kronis, sirosis, dan lebih jauh lagi menyebabkan kanker hati. Diperkirakan lebih dari 170 juta orang penduduk di dunia menderita $\mathrm{HCV}^{2}$ HCV termasuk virus famili Flaviviridae, genus Hepacivirus dengan genom berupa RNA untai tunggal, positive sense, terdiri atas open reading frame (ORF) yang diapit oleh untranslated region (UTR). ORF menyandi sekitar 3000 asam amino untuk membentuk poliprotein yang terbagi menjadi protein struktural (Core, E1, E2) dan nonstruktural (p7, NS2, NS3, NS4A, NS4B, NS5A, NS5B). ${ }^{3,4}$ $\mathrm{HCV}$ memiliki tingkat variasi genetik yang tinggi, dikelompokkan ke dalam tujuh genotipe dan banyak subtipe dengan distribusi yang berbedabeda di setiap wilayah. ${ }^{5,6}$

Diagnosis yang akurat sangat diperlukan untuk memberikan penanganan tepat secara dini, termasuk mencegah penularan virus tersebut secara lebih lanjut. ${ }^{7}$ Metode diagnosis infeksi $\mathrm{HCV}$ telah berkembang dengan pesat sejak virus tersebut berhasil diidentifikasi, salah satunya adalah enzyme immuno assay (EIA) yang digunakan untuk mendeteksi antibodi antiHCV. Pengembangan EIA generasi sebelumnya dilakukan menggunakan antigen rekombinan multipel yang terdiri dari protein HCV struktural dan nonstruktural untuk meningkatkan sensitifitas dan spesifisitas diagnotik. ${ }^{8}$ Hal tersebut dilakukan berdasarkan penambahan jumlah dan penggunaan hampir seluruh sekuen antigen. Kelemahan pengembangan tersebut berpotensi dapat meningkatkan kompleksitas antigen, menurunkan efisiensi produksi, dan meningkatkan biaya yang diperlukan. Pengembangan antigen rekombinan HCV berbasis epitop multipel adalah salah satu cara yang dapat dilakukan untuk mengatasi permasalahan tersebut. Antigen rekombinan $\mathrm{HCV}$ dapat disusun berdasarkan atas epitop yang bersifat imunodominan, lestari, dan mewakili subtipe HCV baik yang bersirkulasi di Indonesia maupun global. ${ }^{9}$ Tujuan penelitian ini adalah mengonstruksi plasmid pengekspresi antigen rekombinan berbasis epitop multipel untuk deteksi antibodi anti-HCV.

\section{METODE}

Kegiatan penelitian dilaksanakan di laboratorium Pusat Riset Virologi dan Kanker Patobiologi, Fakultas Kedokteran Universitas Indonesia-Rumah Sakit Cipto Mangunkusumo (PRVKP FKUI-RSCM) dari Desember 2017 sampai dengan Maret 2018. Gen penyandi antigen rekombinan $\mathrm{HCV}$ dirancang melalui studi bioinformatik dan literatur untuk menentukan epitop dalam penyusunan antigen. Studi bioinformatik dilakukan di antaranya menggunakan piranti lunak NCBI (https://www. ncbi.nlm.nih.gov/) untuk memperoleh sekuen asam amino antigen $\mathrm{HCV}$, immune epitope database (http://www.iedb.org/) untuk analisis epitop bersifat imunodominan, kemudian mega software dan bioedit untuk analisis epitop bersifat lestari. Gen penyandi antigen rekombinan $\mathrm{HCV}$ diperoleh dengan teknologi DNA sintetik (dari perusahaan Macrogen) setelah dilakukan optimasi kodon untuk sistem ekspresi pada sel E. coli. Optimasi kodon tersebut dilakukan menggunakan piranti lunak gene designer 2.0 dan genscript (https://www.genscript.com/).

DNA sintetik antigen rekombinan $\mathrm{HCV}$ diperoleh dalam bentuk terklona pada plasmid pUC57 diapit situs restriksi BamHI dan HindIII (plasmid tersebut kemudian diberi nama pUC57HCV_ME). Sel E. coli Top10 digunakan sebagai inang untuk amplifikasi plasmid pUC57-HCV ME. Sel E. coli Top10 dikultur dalam medium luria bertani (LB) cair kemudian dibuat menjadi sel kompeten dengan menggunakan $100 \mathrm{mM} \mathrm{MgCl} 2$ dan $100 \mathrm{mM} \mathrm{CaCl}$. Plasmid pUC57-HCV_ME (50 ng/ $\mu \mathrm{l})$ ditransformasi pada sel kompeten E. coli Top10 sebanyak $1 / 10$ volume sel dengan cara heat schock pada suhu $38^{\circ} \mathrm{C}$ selama 90 detik, kemudian segera dipindahkan pada suhu $4^{\circ} \mathrm{C}$ selama 60 detik. Sel E. coli Top10 hasil transformasi ditumbuhkan pada LB agar mengandung ampisilin (16 jam, suhu 37 0C). Koloni sel E. coli Top10 yang tumbuh dikonfirmasi dengan cara dilakukan isolasi plasmid skala kecil sesuai prosedur Miniprep (Qiagen), kemudian direstriksi menggunakan enzim BamHI dan HindIII (Biolabs), dan hasilnya divisualisasi dengan elektroforesis agarose $0,8 \%(\mathrm{~b} / \mathrm{v}) 100 \mathrm{~V}$ 25 menit. Vektor ekspresi yang digunakan dalam penelitian ini adalah plasmid pQE80L (Qiagen) yang disimpan dalam stok kultur sel E. coli Top10 di laboratorium. Sel bakteri tersebut ditumbuhkan, 
dilakukan isolasi plasmid, dianalisis dengan restriksi enzimatik seperti dilakukan pada plasmid pUC57-HCV_ME, kemudian divisualisasi dengan elektroforesis jel agarose. ${ }^{10}$

Masing-masing koloni sel E. coli Top10 yang positif mengandung plasmid pUC57-HCV ME dan pQE80L dari hasil isolasi plasmid skala kecil serta analisis restriksi, kemudian dikultur dalam LB cair $(500 \mathrm{ml})$ untuk isolasi plasmid skala besar sesuai prosedur HiSpeed Maxi Kit (Qiagen). Analisis restriksi dengan enzim BamHI dan HindIII kembali dilakukan terhadap plasmid pUC57-HCV_ME dan pQE80L hasil isolasi plasmid skala besar, kemudian divisualisasi dengan elektroforesis agarose $0,8 \%(\mathrm{~b} / \mathrm{v}) 100 \mathrm{~V}$ 25 menit. Setelah diketahui masing-masing plasmid memiliki ukuran yang sesuai, selanjutnya dilakukan restriksi skala besar untuk menyiapkan DNA sisipan dan vektor ekspresi. Berat masingmasing DNA pada campuran reaksi ini sekitar 10000 ng. Hasil restriksi kemudian dipurifikasi dengan pemisahan pada low melting agarose (LMA) dan dilanjutkan dengan tahapan desalting sesuai prosedur QiaexII (Qiagen). Khusus vektor ekspresi pQE80L, untuk mencegah autoligasi setelah plasmid tersebut direstriksi, dilakukan reaksi defosfatasi menggunakan enzim alkaline phosphatase. Selanjutnya visualisasi DNA hasil purifikasi dilakukan dengan elektroforesis agarose $0,8 \%(\mathrm{~b} / \mathrm{v}) 100 \mathrm{~V} 25$ menit. DNA sisipan dan vektor ekspresi yang berukuran sesuai kemudian diligasi dengan enzim T4 DNA ligase dengan perbandingan konsentrasi antara DNA sisipan dengan vektor 3:1. Campuran reaksi ini kemudian diinkubasi pada inkubator dengan suhu $16{ }^{\circ} \mathrm{C}$ selama 16 jam. ${ }^{10}$

Reaksi ligasi antara vektor ekspresi dengan DNA sisipan antigen rekombinan HCV akan menghasilkan plasmid rekombinan pQE80LHCV ME. Sel E. coli Top10 yang telah dibuat kompeten kemudian ditransformasi dengan plasmid tersebut dan ditumbuhkan pada LB agar mengandung ampisilin. Untuk mengetahui keberhasilan konstruksi plasmid tersebut, dilakukan tiga tahap verifikasi yaitu PCR koloni, analisis restriksi, dan sekuensing. Campuran PCR koloni untuk satu reaksi (satu tabung) adalah sebagai berikut: 10 Unit/ $\mu$ l enzim Dream Taq polimerase $0,06 \mu 1,10 x$ bufer enzim Dream Taq polimerase $1 \mu 1,10 \mathrm{mM}$ dNTP mix $0,2 \mu 1,25$ $\mathrm{mM} \mathrm{MgCl} 20,5 \mu \mathrm{l}, 10 \mu \mathrm{M}$ primer $\mathrm{pQE}$ forward $0,2 \mu \mathrm{l}, 10 \mu \mathrm{M}$ primer $\mathrm{pQE}$ reverse $0,2 \mu \mathrm{l}, 1$ koloni transforman, dan $\mathrm{H} 2 \mathrm{O}$ sampai volume total $10 \mu \mathrm{l}$. PCR dilakukan terhadap 10 koloni, sebanyak 35 siklus yang terdiri atas tahap denaturasi $\left(95{ }^{\circ} \mathrm{C}\right)$
30 detik, annealing $\left(55^{\circ} \mathrm{C}\right) 30$ detik, dan elongasi $\left(72{ }^{\circ} \mathrm{C}\right) 45$ detik. Selanjutnya visualisasi hasil PCR koloni dilakukan dengan elektroforesis agarose $0,8 \%(\mathrm{~b} / \mathrm{v}) 100 \mathrm{~V} 25$ menit. Klon yang positif dari hasil PCR koloni kemudian diverifikasi lebih lanjut dengan analsis restriksi menggunakan enzim BamHI dan HindIII. Klon yang positif berdasarkan dua tahap verifikasi tersebut kemudian digunakan untuk analisis sekuensing dengan metode Sanger. ${ }^{10}$

\section{HASIL}

Konstruksi plasmid pengekspresi antigen rekombinan HCV diawali dengan penyiapan DNA sisipan. Setelah diperoleh gen penyandi antigen rekombinan $\mathrm{HCV}$ yang dibuat melalui teknologi DNA sintetik dan telah terklona dalam bentuk plasmid pUC57-HCV ME, plasmid tersebut kemudian ditransformasi pada sel E. coli Top10. Konsentrasi plasmid pUC57-HCV_ME hasil isolasi plasmid skala kecil dari empat buah koloni masing-masing 228,4 ng/ $\mu 1,198,1 \mathrm{ng} / \mu 1,201,3$ $\mathrm{ng} / \mu \mathrm{l}$, dan $224,3 \mathrm{ng} / \mu \mathrm{l}$. Plasmid tersebut kemudian dianalisis dengan enzim restriksi BamHI dan HindIII, kemudian hasilnya divisualisasi dengan elektroforesis jel agarose (Gambar 1). Plasmid pUC57-HCV ME yang tidak dipotong enzim restriksi berukuran $3910 \mathrm{pb}$ (lajur 1, 3, 5, dan 7). Plasmid pUC57-HCV ME yang dipotong enzim restriksi (lajur 2, 4, 6, dan 8) pada elektroforesis jel agarose menghasilkan dua fragmen DNA, masing masing terdiri atas DNA sisipan HCV_ME berukuran $1200 \mathrm{pb}$ dan kerangka plasmid pU⿱C一)57 berukuran $2710 \mathrm{pb}$.

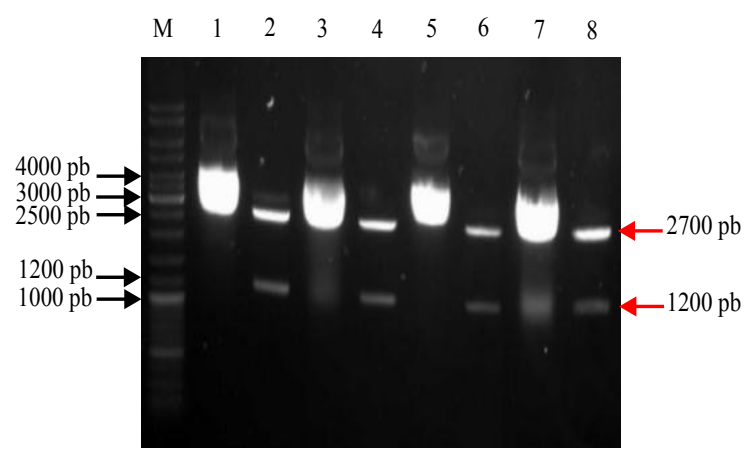

Gambar 1. Elektroforesis Jel Agarose Plasmid pUC57-HCV_ME Hasil Isolasi Skala Kecil Dari Sel E. coli Top10. M: Marka. Lajur 1, 3, 5, 7: Plasmid pUC57-HCV_ME dari Koloni 1, 2, 3, dan 4 Tidak Dipotong Enzim Restriksi. Lajur 2, 4, 6, 8: Plasmid pUC57-HCV_ME dari Koloni 1, 2, 3, dan 4 Dipotong dengan Enzim Restriksi BamHI dan HindIII 
Selanjutnya penyiapan vektor ekspresi dilakukan dengan menumbuhkan sel E. coli Top10 yang mengandung plasmid pQE80L dari stok klutur yang ada di laboratorium. Konsentrasi plasmid pQE80L hasil isolasi plasmid skala kecil dari empat buah koloni masing-masing 164,5 $\mathrm{ng} / \mu 1,139,8 \mathrm{ng} / \mu 1,172,5 \mathrm{ng} / \mu \mathrm{l}$, dan 155,8 ng/ $\mu 1$. Plasmid tersebut kemudian dianalisis dengan enzim restriksi BamHI dan HindIII. Visualisasi elektroforesis jel agarose terhadap hasil restriksi tersebut ditunjukkan pada Gambar 2. Plasmid pQE80L yang tidak dipotong oleh enzim restriksi berukuran $4751 \mathrm{pb}$ (plasmid pQE80L wild type) (lajur 1, 3, 5, dan 7). Selanjutnya pemotongan dengan enzim restriksi BamHI dan HindIII, menjadikan plasmid tersebut berukuran $4709 \mathrm{pb}$, residu fragmen DNA $42 \mathrm{pb}$ tidak terlihat pada visualisasi jel agarose (lajur 2, 4, 6, dan 8).

Setelah mendapatkan ukuran pita DNA yang sesuai berdasarkan elektroforesis jel agarose (analisis Gambar 1 dan 2), salah satu koloni (dipilih koloni 1) digunakan untuk isolasi plasmid skala besar. Isolasi plasmid tersebut yaitu plasmid pUC57-HCV_ME untuk menyiapkan DNA sisipan dan plasmid pQE80L untuk menyiapkan vektor ekspresi. Konsentrasi plasmid pUC57HCV_ME dan pQE80L yang diperoleh dari hasil isolasi ini masing-masing yaitu $255,8 \mathrm{ng} /$ $\mu 1$ dan $82,5 \mathrm{ng} / \mu \mathrm{l}$. Plasmid tersebut kemudian dikonfirmasi dengan analisis restriksi (BamHI dan HindIII), dan hasilnya divisualisasi dengan elektroforesis jel agarose (Gambar 3). Pita DNA sisipan antigen rekombinan HCV berukuran 1200 $\mathrm{pb}$, ditunjukkan pada lajur 2. Adapun plasmid pQE80L yang telah dipotong enzim restriksi berukuran sebesar $4709 \mathrm{pb}$ (lanjur 4). Hal ini sesuai dengan hasil isolasi plasmid sebelumnya pada skala kecil. Plasmid pUC57-HCV_ME (lajur 1) dan pQE80L (lajur 3) yang tidak dipotong oleh enzim restriksi masing-masing berukruan 3910 pb dan $4751 \mathrm{pb}$. Pada lajur kedua Gambar 3 tampak pita DNA berukuran sekitar 4000 pb yang berada di atas pita berukuran sekitar $2710 \mathrm{pb}$. Pita berukuran sekitar $4000 \mathrm{pb}$ tersebut diduga adalah plasmid pUC57-HCV_ME (3910 pb) yang tidak terpotong sempurna oleh enzim restriksi atau hanya terpotong oleh salah satu dari dua enzim restriksi yang digunakan (BamHI dan HindIII).

Setelah memperoleh hasil yang sesuai pada analisis restriksi plasmid dari hasil isolasi skala besar, selanjutnya dilakukan restriksi skala besar (sekitar $10000 \mathrm{ng}$ ) untuk penyiapan ligasi antara DNA sisipan dan vektor ekspresi. Hasil restriksi ini dipurifikasi kemudian divisualisasi dengan elektroforesis jel agarose (Gambar 4). Lajur 1 dan 2 masing-masing menunjukkan pita DNA sisipan antigen rekombinan $\mathrm{HCV}$ berukuran $1200 \mathrm{pb}$ dan vektor ekspresi pQE80L berukuran $4709 \mathrm{pb}$. Adapun konsentrasi DNA yang diperoleh dari hasil purifikasi ini yaitu14,3 ng/ $\mu 1$ untuk DNA sisipan antigen rekombinan $\mathrm{HCV}$ dan 37,5 ng/ $\mu 1$ untuk plasmid pQE80L.

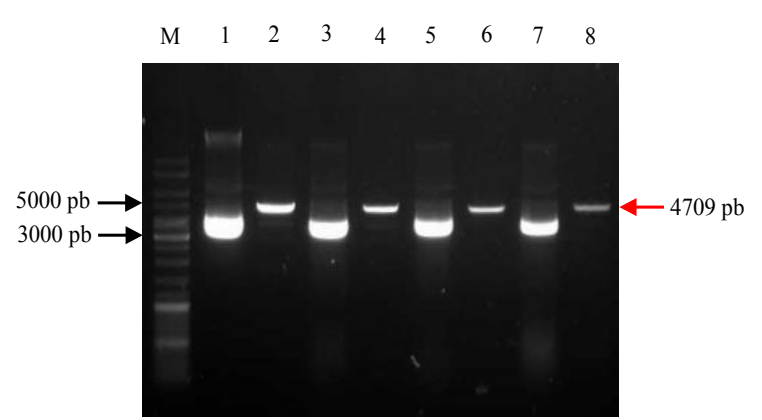

Gambar 2. Elektroforesis Jel Agarose Plasmid pQE80L Hasil Isolasi Skala Kecil dari Sel E. coli Top10. M: Marka. Lajur 1, 3, 5, 7: Plasmid pQE80L dari Koloni 1, 2, 3, dan 4 Tidak Dipotong Enzim Restriksi. Lajur 2, 4, 6, 8: Plasmid pQE80L dari Koloni 1, 2, 3, dan 4 Dipotong Dengan Enzim Restriksi BamHI dan HindIII

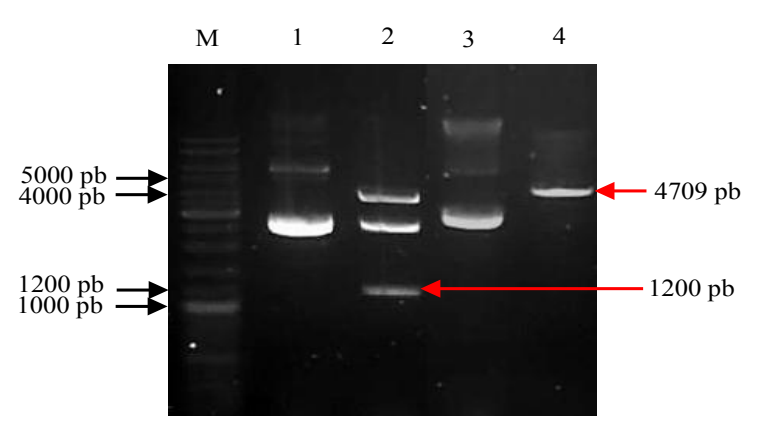

Gambar 3. Elektroforesis Jel Agarose Plasmid pUC57-HCV_ME dan pQE80L Hasil Isolasi Skala Besar dari sel $E$. coli Top10. M: Marka. Lajur 1 dan 3: Plasmid pUC57-HCV_ME dan pQE80L Tidak Dipotong Enzim Restriksi. Lajur 2 dan 4: Plasmid pUC57-HCV_ME dan pQE80L Dipotong dengan Enzim Restriksi BamHI dan HindIII.

Ligasi antara DNA sisipan antigen rekombinan HCV (1200 pb) dengan vektor ekspresi pQE80L (4709 pb) menghasilkan plasmid rekombinan pQE80L-HCV_ME (5909 pb). Tabel 1 menunjukkan jumlah koloni sel $E$. coli Top10 hasil transformasi plasmid pQE80LHCV_ME yang tumbuh pada medium LB 
agar mengandung ampisilin. Sebagai kontrol, disertakan pula transformasi plasmid pQE80L $(4709 \mathrm{pb})$ hasil purifikasi setelah direstriksi oleh enzim BamHI dan HindIII dan plasmid pQE80L (4751 pb) wild type atau tidak dipotong oleh enzim restriksi BamHI dan HindIII. Selain itu disertakan pula sel E. coli Top10 yang tidak ditransformasi oleh plasmid.

Untuk memverifikasi keberhasilan konstruksi plasmid pQE80L-HCV_ME sebagai pengekspresi antigen rekombinan $\mathrm{HCV}$, tahap pertama dilakukan PCR koloni. Sebanyak 9 dari 10 koloni yang dianalisis dengan PCR menunjukkan hasil positif. Hal ini ditandai dengan adanya pita DNA dengan ukuran sekitar $1450 \mathrm{pb}$ (lajur 1-7 dan 9-10). Lajur 8 adalah koloni negatif dari hasil analisis PCR, sementara lajur 11 dan 12 masingmasing adalah kontrol positif dan kontrol negatif reaksi PCR. Pada kontrol positif digunakan plasmid $\mathrm{pQE} 80 \mathrm{~L}$ wild type pada campuran reaksi PCR sebagai DNA template (menghasilkan pita DNA berukuran sekitar $250 \mathrm{pb}$ ). Sementara pada kontrol negatif, tidak terdapat DNA template dalam campuran reaksi PCR, sehingga tidak menghasilkan pita DNA pada elektroforesis jel agarose (Gambar 5).

Selanjutnya verifikasi tahap kedua adalah analsis restriksi. Plasmid pQE80L-HCV_ME diisolasi dari koloni sel E. coli Top10 yang positif berdasarkan analisis PCR (dipilih koloni 1-5). Dari hasil isolasi tersebut diperoleh konsentrasi plasmid pQE80L-HCV_ME berturut-turut 115,9 $\mathrm{ng} / \mu 1,81,9 \mathrm{ng} / \mu \mathrm{l}, 100, \overline{4} \mathrm{ng} / \mu \mathrm{l}, 101,5 \mathrm{ng} / \mu \mathrm{l}$, dan $106,2 \mathrm{ng} / \mu \mathrm{l}$. Plasmid tersebut kemudian dipotong dengan enzim restriksi BamHI dan HindIII yang hasilnya ditunjukkan pada Gambar 6. Plasmid pQE80L-HCV_ME yang tidak dipotong enzim restriksi berukuran 5909 pb (lajur 1, 3, 5, 7 dan 9). Sedangkan plasmid pQE80L-HCV_ME yang dipotong enzim restriksi menghasilkan dua pita DNA pada elektroforesis jel agarose. Pita tersebut masing-masing berukuran $4709 \mathrm{pb}$ dan $1200 \mathrm{pb}$ yang berasal dari vektor ekspresi pQE80L dan DNA sisipan antigen rekombinan HCV. Lajur 11 adalah plasmid pQE80L wild type $(4751 \mathrm{pb})$ yang tidak dipotong oleh enzim restriksi yang berfungsi sebagai kontrol. Plasmid pQE80L-HCV_ME (dipilih dari koloni nomor 1) digunakan untuk verifikasi tahap ketiga yaitu analisis sekuensing. Hasilnya menunjukkan tidak terdapat mutasi pada susunan DNA penyandi antigen rekombinan HCV (hasil sekuensing tidak dilampirkan karena dalam proses pengajuan hak paten).

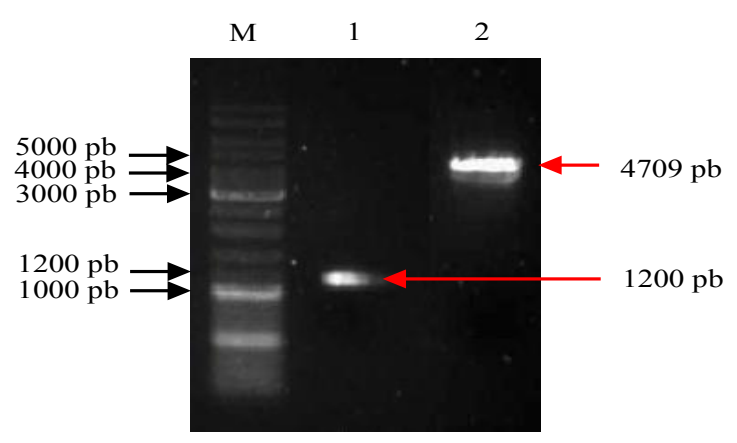

Gambar 4. Elektroforesis Jel Agarose Hasil Purifikasi DNA Sisipan dan Vektor Ekspresi. M: Marka. Lajur 1: DNA Sisipan HCV_ME. Lajur 2: Vektor Ekspresi pQË80L

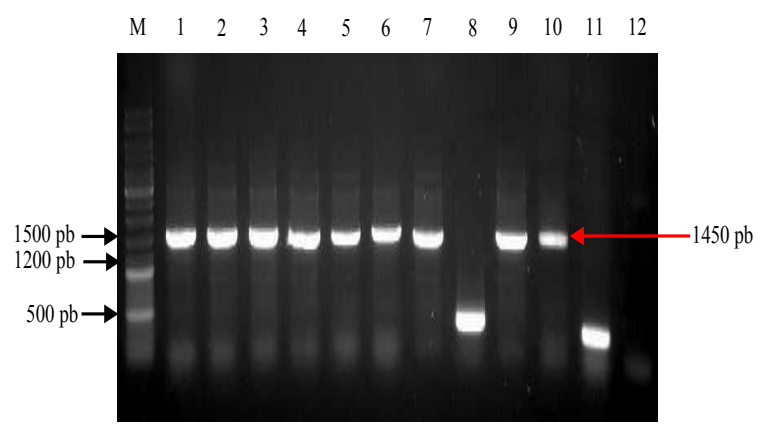

Gambar 5. Elektroforesis Jel Agarose Hasil PCR Koloni E. coli Top10. M: Marka. Lajur 1-10: Koloni E. coli Top10 Hasil Transformasi Plasmid pQE80L-HCV_ME. Lajur 11: Kontrol Positif PCR Koloni. Lajur 12: Kontrol Negatif PCR Koloni.

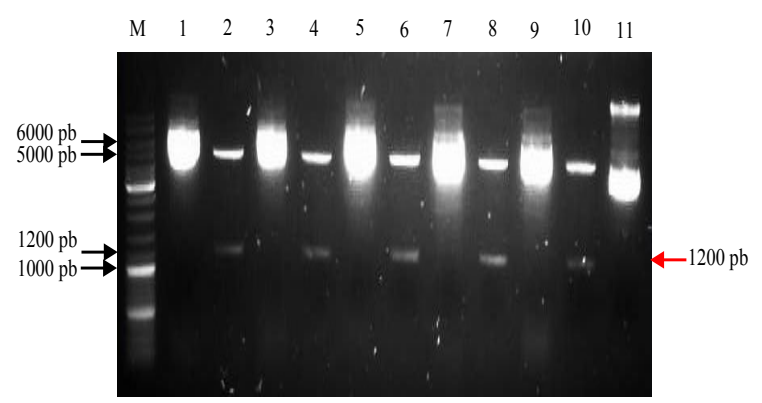

Gambar 6. Elektroforesis Jel Agarose Hasil Restriksi Plasmid pQE80L-HCV ME. M: Marka. Lajur 1, 3, 5, $\overline{7}$, 9: Plasmid pQE80L-HCV_ME dari Koloni 1, 2, 3, 4, dan 5 Tidak Dipotong Enzim Restriksi. Lajur 2, 4, 6, 8, 10: Plasmid pQE80L-HCV ME dari Koloni 1, 2, 3, 4, dan $\overline{5}$ dipotong dengan Enzim Restriksi BamHI dan HindIII. Lajur 11: Plasmid pQE80L wild type Tidak Dipotong Enzim Restriksi. 
Tabel 1. Koloni Sel E. coli Top10 Hasil Transformasi

\begin{tabular}{lc}
\hline \multicolumn{1}{c}{ DNA yang ditransformasi } & $\begin{array}{c}\text { Jumlah koloni } \\
\text { yang tumbuh }\end{array}$ \\
\hline pQE80L-HCV_ME (Plasmid hasil ligasi) & 342 \\
pQE80L hasil restriksi enzim BamHI dan & 7 \\
HindIII (Kontrol ligasi) & 900 \\
pQE80L wild type (Kontrol positif & \\
transformasi) & 0 \\
$\begin{array}{l}\text { Kontrol negatif transformasi (E. coli Top10 } \\
\text { tanpa diberi plasmid) }\end{array}$ & \\
\hline
\end{tabular}

\section{PEMBAHASAN}

Diagnosis yang akurat untuk deteksi $\mathrm{HCV}$ sangat diperlukan mengingat virus tersebut memiliki variasi genetik (heterogenitas) yang tinggi disertai distribusi yang berbeda-beda di setiap wilayah. ${ }^{67}$ Pada penelitian ini dilakukan pengembangan antigen rekombinan HCV berbasis epitop multipel untuk deteksi antibodi anti-HCV. Epitop target yang digunakan untuk menyusun antigen rekombinan $\mathrm{HCV}$ berasal dari protein core, NS3, NS4AB, NS4B, dan NS5A. Epitop yang digunakan tersebut adalah epitop yang bersifat imunodominan, lestari, serta dirancang dapat mewakili subtipe HCV yang bersirkulasi di Indonesia (1a, 1b, 1c, 2, 3) dan global. ${ }^{6} \mathrm{Hal}$ ini dilakukan untuk meningkatkan efisiensi produksi antigen yang memiliki sensitivitas dan spesifisitas yang baik termasuk mengakomodasi berbagai subtipe HCV. Penelitian sebelumnya yang hanya mengakomodasi subtipe-subtipe HCV tertentu. ${ }^{11-12}$

Gen penyandi antigen rekombinan HCV pada penelitian ini dibuat dengan teknik DNA sintetik setelah dilakukan proses optimasi kodon untuk sistem ekspresi E. coli. Keuntungan teknik ini yaitu dapat meningkatkan efisiensi perancangan DNA, adapun optimasi kodon dilakukan untuk meningkatkan efisiensi ekspresi protein pada sel inang yang digunakan. ${ }^{13}$ Pada beberapa penelitian sebelumnya, perancangan DNA dilakukan dengan RT-PCR. ${ }^{11-12}$ Pada penelitian ini gen penyandi antigen rekombinan $\mathrm{HCV}$ diterima dari perusahaan penyedia jasa sintesis DNA dalam bentuk telah terklona pada plasmid pUC57-HCV_ME. Gen sintetik tersebut selanjutnya dikonstruksi atau disubklona pada vektor ekspresi pQE80L. ${ }^{14}$ Plasmid pUC57 yang mengandung gen antigen rekombinan $\mathrm{HCV}$ ditransformasi pada sel kompeten E. coli Top10 untuk dipropagasi dan dikonfirmasi. Pembuatan sel kompeten dilakukan dengan prinsip sel bakteri dilubangi menggunakan kalsium konsentrasi tinggi sehingga dapat menangkap DNA bebas dari luar sel. DNA dipakasa masuk ke dalam sel melalui lubang tersebut dengan adanya perubahan suhu yang mendadak. Plasmid pUC57 mengandung gen penyandi faktor resistensi ampisilin yang digunakan untuk seleksi sel transforman. ${ }^{15}$

Penyiapan DNA sisipan dan vektor ekspresi dilakukan melalui pemotongan plasmid pUC57-HCV_ME dan plasmid pQE80L dengan enzim BamHI dan HindIII. Pemotongan plasmid pUC57-HCV_ME bertujuan untuk memisahkan DNA sisipan antigen rekombinan HCV (1200 pb) dari kerangka plasmid pUC57 (2710 pb). Adapun pemotongan plasmid pQE80L bertujuan menyiapkan plasmid tersebut sehingga dapat disisipi oleh DNA antigen rekombinan $\mathrm{HCV}$. Pemotongan enzim BamHI dan HindIII pada plasmid pQE80L membuat plasmid tersebut terlinierisasi dari awalnya berbentuk sirkuler. Ukuran plasmid pQE80L sebelum dipotong oleh enzim restriksi (BamHI dan HindIII) yaitu $4751 \mathrm{pb}$ (berbentuk sirkuler), kemudian setelah dipotong (terlinierisasi) menjadi 4709 pb (tereduksi sebanyak 42 pb). Enzim BamHI memotong plasmid pada situs GGATCC di ujung 5', sedangkan enzim HindIII memotong pada situs AAGCTT di ujung 3'. Kedua enzim restriksi tersebut menghasilkan pola pemotongan ujung lancip (sticky end). Hal ini membantu proses ligasi antara DNA sisipan dengan vektor ekspresi menjadi lebih efisien karena ujung lancip yang bebas dari hasil pemotongan enzim restriksi dapat saling berpasangan dengan komplemen ujung lancip lain melalui ikatan hidrogen. ${ }^{16}$

Purifikasi hasil restriksi plasmid pUC57HCV_ME dan pQE80L dilakukan dengan pemisahan pada low melting agarose (LMA) dan dilanjutkan dengan tahapan desalting sesuai prosedur QiaexII (Qiagen). Prinsip LMA adalah memisahkan fragmen DNA berdasarkan kecepatan migrasi dalam arus listrik yang dipengaruhi oleh ukuran DNA tersebut. DNA berukuran lebih besar memiliki jarak migrasi lebih dekat dibandingkan DNA berukuran kecil. Berdasarkan hal ini fragmen DNA target dapat terpisah dari fragmen DNA non-target. Prinsip desalting dengan QiaexII didasarkan pada kemampuan DNA untuk berikatan dengan partikel silika, kemudian garam dan protein kontaminan akan terbuang pada saat pencucian. ${ }^{17,18}$

Ligasi antara DNA sisipan antigen 
rekombinan HCV dengan plasmid pQE80L terjadi berdasarkan pembentukan ikatan fosfodiester dan ikatan hidrogen pada ujung sticky end yang saling berkomplementasi dari masing-masing DNA. ${ }^{19}$ Hasil ligasi ini menghasilkan plasmid pQE80LHCV ME yang kemudian ditransformasi pada E. coli Top10 untuk dipropagasi dan diverifikasi. Jumlah koloni E. coli Top10 yang tumbuh dari hasil transformasi plasmid pQE80L-HCV ME (Tabel 1) sekitar 48 kali lebih banyak dibandingkan kontrol ligasi, hal ini dapat menunjukkan adanya keberhasilan reaksi ligasi. Kemudian adanya koloni yang tumbuh dari kontrol ligasi kemungkinan menunjukkan terdapat vektor yang belum terpotong. Selanjutnya adanya koloni yang tumbuh pada kontrol positif transformasi dan tidak terdapat koloni yang tumbuh pada kontrol negatif juga dapat menunjukkan keberhasilan transformasi dan pembuatan sel kompeten, termasuk dalam hal ini menunjukkan tidak adanya kontaminasi.

PCR koloni dengan primer pQE forward dan $\mathrm{pQE}$ reverse mengamplifikasi DNA sisipan antigen rekombinan HCV yang diapit oleh situs pengklonaan BamHI dan HindIII. Dari amplifikasi ini dihasilkan pita DNA berukuran $1450 \mathrm{pb}$ yang merupakan gabungan dari DNA sisipan berukuran $1200 \mathrm{pb}$ ditambah DNA dari plasmid $250 \mathrm{pb}$. Dengan demikian apabila pada plasmid pQE80L tidak terdapat DNA sisipan antigen rekombinan $\mathrm{HCV}$, maka pita DNA yang dihasilkan yaitu 250 $\mathrm{pb}$ (seperti ditunjukkan oleh koloni nomor 8 dan lajur 11 Gambar 5). Berdasarkan analisis restriksi (koloni nomor 1-5 yang positif dari hasil PCR), plasmid pQE80L-HCV_ME berukuran sesuai dengan yang diharapkan (5909 pb). Ukuran ini adalah gabungan antara DNA sisipan antigen rekombinan HCV (1200 pb) dan plasmid pQE80L (4709 pb) (Gambar 6).

Analisis sekuensing dilakukan dengan cara melakukan alignment antara DNA sampel (plasmid hasil isolasi dari koloni nomor 1 yang positif berdasarkan PCR dan analisis restriksi) dengan DNA referensi (susunan DNA penyandi antigen rekombinan $\mathrm{HCV}$ yang dibuat gen sintetik). Alignment dilakukan menggunakan piranti lunak mega software. Hasilnya DNA yang dianalisis sesuai dengan DNA referensi yaitu sebagai gen penyandi antigen rekombinan $\mathrm{HCV}$. Selain tidak terdapat mutasi, gen tersebut juga berada pada open reading frame yang sesuai pada plasmid pQE80L.

\section{KESIMPULAN}

Plasmid pQE80L-HCV ME pengekspresi antigen rekombinan $\overline{\mathrm{HCV}}$ berbasis epitop multipel telah berhasil dikonstruksi dan terverifikasi melalui uji PCR, analisis restriksi, dan sekuensing.

\section{SARAN}

Selanjutnya plasmid pQE80L-HCV_ME yang telah berhasil dikonstruksi pada penelitian ini ke depan dapat digunakan untuk memproduksi antigen rekombinan $\mathrm{HCV}$ yang dimanfaatkan untuk deteksi antibodi anti-HCV. Antigen rekombinan tersebut dapat diekspresikan pada sel prokariot seperti pada $E$. coli BL21, kemudian dipurifikasi dengan kromatografi afinitas dengan memanfaatkan polihistidin yang ada pada vektor ekspresi.

\section{UCAPAN TERIMA KASIH}

Ucapan terima kasih penulis sampaikan kepada dr. Fera Ibrahim, M.Sc., P.hD., Sp.MK(K) selaku pimpinan laboratorium PRVKP FKUIRSCM, kemudian kepada para staf peneliti dan juga rekan-rekan di laboratorium tempat penulis mengerjakan penelitian. Terima kasih pula penulis sampaikan kepada PRVKP FKUI-RSCM yang telah mendanai penelitian ini.

\section{DAFTAR PUSATAKA}

1. Suzuki $\mathrm{T}$, Ishii $\mathrm{K}$, Aizaki $\mathrm{H}$, Wakita $\mathrm{T}$. Hepatitis C viral life cycle. Advanced Drug Delivery Reviews. 2007;57:1200-1212.

2. Kanda T, Yokosuka O, Omata M. Hepatitis C virus and hepatocellular carcinoma. Biology. 2013;2:304-316.

3. Dubuisson J, Cosset F. Virology and cell biology of the hepatitis $\mathrm{C}$ virus life cycle. Journal of Hepatology. 2014;61:3-13.

4. Chen SL, Morgan TR. 2006. The natural history of hepatitis $\mathrm{C}$ virus (HCV) infection. J. Med. Sci. 2006;3:47-52.

5. Zein NN. Clinical significance of hepatitis C virus genotypes. Journal of Clinical Microbiology. 2000;13(2):223-235.

6. Bukh J. The history of hepatitis $\mathrm{C}$ virus (HCV): basic research reveals unique feature in phylogeny, evolution and the viral life cycle with new perspective for epidemic control. Journal of Hepatology. 2016;65:221.

7. Li Hui-Chun, Lo Shih-Yen. Hepatitis $\mathrm{C}$ virus: virology, diagnosis and treatment. World Journal of Hepatology. 2015;7(10):13771389. 
8. Richter SS. Laboratory assays for diagnosis and management of hepatitis $\mathrm{C}$ virus infection. Journal of Clinical Microbiology. 2002;40(12):4407-4412.

9. Galdino AS et al. A novel structurally stable multiepitope prottein for detection of HCV. Hepatitis Research and Treatment. 2016;1-9.

10. PRVKP FKUI-RSCM. Protokol pembuatan DNA rekombinan. Jakarta: Universitas Indonesia; 2013.

11. Ali A, Nisar M, Idrees M, Rafique S, Iqbal M. Expression of hepatitis $C$ virus core and E2 antigenic recombinant proteins and their ue for development of diagnostic assays. International Journal of Infectious Diseases. 2015;34:84-89.

12. Dipti CA, jain SK, Navin K. A novel recobinant multiepitope protein as a hepatitis $\mathrm{C}$ diagnostic intermediate of high sensitivity and specificity. Protein Expression and Purification. 2006;47:319-328.

13. Villalobos A, Ness JE, Gustafsson C, Minshull J, Govindarajan S. Gene designer: a synthetic biology tool for constructing artificial DNA segments. Biomed Central. 2006;7:1-8.

14. Qiagen. The QIAexpressionist: A handbook for high-level expression and purification of 6x-histagged proteins 5th ed. UDA: Qiagen; 2003.

15. Zhiming $\mathrm{Tu}$ et al. An improved system for competent cell preparation and high efficiency plasmid transformation using different Escherchia coli starin. Electronic Journal of Biotechnology. 8(1):114-120.

16. Brown T. Gene cloning \& DNA analysis an introduction. 6th ed. Oxford: WileyBlackwell; 2010.

17. Qiagen. QIAEXII Handbook for DNA extraction from agarose and polyacrilamide jels and for desalting and concentrating DNA from solutions. Qiagen; 2015.

18. Sambrook J, Russel DW. Molecular cloning: A laboratory manual. 1st-3rd ed. New York: Cold Spring Harbor Laboratory Press. 2001.

19. Alberts B et al. Molecular biology of the cell. 5th ed. USA: Garland Science. 2008. 